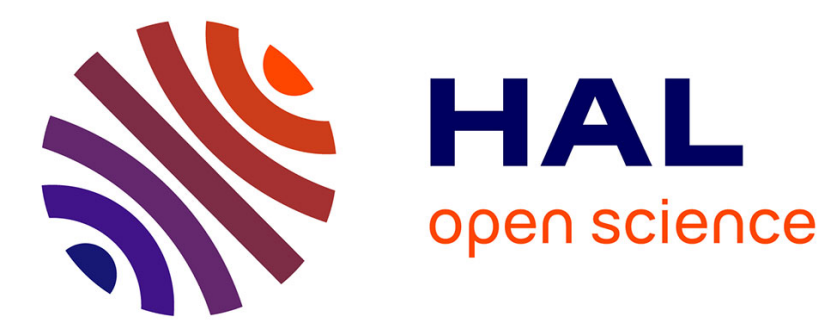

\title{
Prisons et autorités urbaines sous les Abbassides
}

Mathieu Tillier

\section{To cite this version:}

Mathieu Tillier. Prisons et autorités urbaines sous les Abbassides. Arabica, 2008, 55, pp.387-408. halshs-00604063

\section{HAL Id: halshs-00604063 \\ https://shs.hal.science/halshs-00604063}

Submitted on 28 Jun 2011

HAL is a multi-disciplinary open access archive for the deposit and dissemination of scientific research documents, whether they are published or not. The documents may come from teaching and research institutions in France or abroad, or from public or private research centers.
L'archive ouverte pluridisciplinaire HAL, est destinée au dépôt et à la diffusion de documents scientifiques de niveau recherche, publiés ou non, émanant des établissements d'enseignement et de recherche français ou étrangers, des laboratoires publics ou privés. 


\title{
PRISONS ET AUTORITÉS URBAINES SOUS LES ABBASSIDES
}

\author{
par \\ MATHIEU TILLIER
}

L'univers carcéral des premiers siècles de l'Islam est peu documenté : les traités de fiqh, les chroniques, les dictionnaires biographiques et la littérature d'adab n'en offrent qu'une image éclatée et fragmentaire. Grâce à l'étude pionnière d'I. Schneider sur la prison dans le droit musulman, les fonctions de la détention à l'époque classique sont aujourd'hui mieux connues ${ }^{1}$. Plusieurs études récentes ont par ailleurs mis en lumière le fonctionnement théorique ou pratique de l'institution pénitentiaire dans plusieurs domaines du monde musulman médiéval, en particulier au Maghreb et dans l'Égypte mamelouke ${ }^{2}$.

L'inscription du système carcéral au sein de l'État abbasside demeure en revanche plus difficile à appréhender. Comme l'a souligné I. Schneider, l'œuvre d'un juriste iraqien comme al-Hașsāf (m. 261/874) laisse transparaître un schéma bipartite : certaines prisons étaient surtout destinées à la détention préventive ou administrative - dans l'attente d'un châtiment corporel ou en cas de dette -, tandis que d'autres étaient réservées aux voleurs et aux criminels ${ }^{3}$. Cette image, qui laisse dans l'ombre la question de l'autorité dont relèvent ces prisons, demande à être ajustée au regard d'autres textes, en particulier les sources narratives. Le fonctionnement administratif interne des prisons transparaît à travers quelques références textuelles à leur personnel et leur gestion bureaucratique. À un autre niveau, les prisons relevaient d'une hiérarchie jusqu'ici mal connue : l'autorité des cadis sur les établissements où ils envoyaient leurs détenus mérite notamment d'être examinée. La dénomination de certaines prisons, ainsi que leur localisation au sein de l'espace urbain, révèlent enfin leur lien avec les autorités militaires ainsi que leur rôle symbolique à l'intérieur des villes.

\section{La gestion interne des prisons}

\subsection{Le personnel carcéral}

Le nom générique des gardiens de prison était «sağğḡn » (plur. sağğḡāūn), " geôlier ». Ce substantif, le plus fréquemment employé, ne permet pas de déterminer la place ni les fonctions des personnages ainsi désignés: il peut tout aussi bien s'agir de hauts responsables que de simples surveillants. Rarement évoquée dans les sources narratives ${ }^{4}$, une hiérarchie du personnel carcéral transparait néanmoins dans la littérature juridique. Dans son Kitāb al-ḩarāăg Abū Yūsuf conseille le calife al-Rašīd sur la gestion des prisons et des

\footnotetext{
Je remercie Thierry Bianquis et Antoine Borrut pour leurs remarques et leurs suggestions à la lecture de cet article. Les éventuelles erreurs restent de la seule responsabilité de l'auteur.

${ }^{1}$ I. Schneider, «Imprisonment in Pre-classical and Classical Islamic Law », Islamic Law and Society, 2 (1995), p. 157-173.

${ }^{2}$ N. Hentati, «La prison en Occident musulman médiéval », Arabica, 54 (2007), p. 149-188 ; B. Martel-Thoumian, "De l'équité à l'arbitraire: état des prisons et des prisonniers sous les derniers Mamlouks ", Annales Islamologiques, 40 (2006), p. 205-246.

${ }^{3}$ Al-Ḩașșāf, Kitāb adab al-qāḍ̂̄, éd. Farhạāt Ziyāda, Le Caire, The American University in Cairo Press, 1978, p. 264. Voir I. Schneider, art. cit., p. 158 sq, 169.

${ }^{4}$ Sur l'image des geôliers dans la poésie des débuts de l'Islam, voir W. al-Ṣamad, al-Suğūn wa-ataru-hā fì l-ādāb al-'arabiyya, Beyrouth, al-Mu'assasat al-ğāmi iyya li-l-dirāsa wa-l-našr wa-l-tawzî́, 1995, p. 222.
} 
prisonniers, insistant notamment sur leur entretien matériel. Les besoins alimentaires de chaque détenu doivent être évalués et une somme équivalente doit lui être versée car, selon l'auteur, des distributions en nature seraient détournées par les "wulāt al-siğn», les « quwwām » et les « ğalāwiza » ${ }^{5}$. Cette énumération dans un ordre visiblement hiérarchique suggère l'existence d'au moins trois catégories de personnel carcéral.

Le grade le plus élevé était celui de wālī l-siğn (plur. wulāt al-siğn), titre porté par le directeur de la prison - ou peut-être, en certains cas, par une autorité en charge d'un groupe d'établissements. Dans ses Ahbār al-qudāt, Wakî mentionne qu'un gouverneur de Médine, vers 192/808, désigna un responsable de la prison (al-siğn) et un autre des remparts $(a l-s \bar{u} r)^{6}$. Le verbe employé lors de ces investitures («wallaytu-ka») laisse penser que ce responsable portait le titre de wāli l-siğn, conformément à la terminologie mentionnée quelques années plus tôt par Abū Yūsuf. Certains directeurs de prison devaient donc être nommés par le gouverneur de la ville ou de la province. Le titre de wāli l-siğn doit probablement être rapproché de celui de șạhib al-siğn (le «maître de la prison»), qui apparaît parfois dans les sources narratives ${ }^{7}$ : ce dernier désignait, de manière beaucoup plus évidente, un « directeur » d'établissement carcéral.

Le qā’im (plur. quwwām) apparaît généralement comme un «lieutenant», un "préposé ", un " exécutant». Manifestement subordonné au wālī de la prison, ce grade apparaît aussi sous la forme " qayyim ${ }^{8}$, également employé pour désigner le "préposé » à une mosquée ou un hammam ${ }^{9}$. Le rang de ce personnage n'est défini nulle part, mais il devait se trouver quelque part entre le haut fonctionnaire et le surveillant de base : si le wāti était un directeur de prison, le qā’im était probablement une sorte de "surveillant chef »; mais s'il s'agissait d'une plus haute autorité administrative, peut-être le qā’im était-il luimême un directeur d'établissement.

Pour Abū Yūsuf, le ğilwāz (plur. ğalāwiza) semblait correspondre au gardien ordinaire, au

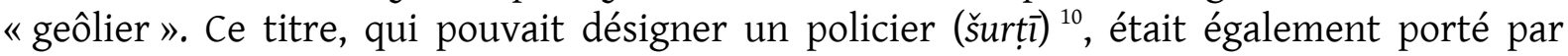
l'auxiliaire du cadi chargé de maintenir l'ordre à l'audience et d'exécuter certains châtiments corporels ${ }^{11}$. Collectivement, les surveillants étaient aussi appelés « al-haras » (la garde) ou "al-ḥurrās» (les gardiens) ${ }^{12}$. Le terme bawwāb sembla enfin désigner, dès la période umayyade, le portier ou le concierge de la prison ${ }^{13}$.

Quels étaient les effectifs de ce personnel ? Comment était-il choisi et rémunéré? Presque aucune information n'est disponible à ce sujet. Le seul wālì l-siğn que nous ayons identifié est Muțarrif b. 'Abd Allāh al-Yasārī (m. 220/835), et encore celui-ci refusa-t-il le

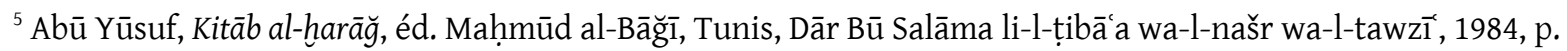
151 (trad. E. Fagnan, dans Abou Yousof Ya'koub, Le livre de l'impôt foncier, Paris, Geuthner, 1921, p. 232).

${ }^{6}$ Wakī', Ahbār al-qudāt, éd. 'Abd al-'Azīz Muștafāà al-Marāḡì̄, Le Caire, Mațba'at al-Sa'āda, 1947-1950, I, p. 254. Le gouverneur, Abū l-Bahtarī Wahb b. Wahb, exerçait aussi la fonction de cadi, mais c'est en tant que gouverneur qu'il effectua ces nominations - comme l'indique le parallèle entre l'autorité sur la prison et celle sur les remparts, cette dernière relevant évidemment d'un gouverneur militaire.

${ }^{7}$ Voir par exemple al-Tabarī, Ta'rịh al-umam wa-l-mulūk, Beyrouth, Dār al-kutub al-ilmiyya, 1997, IV, p. 107, 352 ; al-Dīnawārī, al-Ahbār al-țiwāl, éd. 'Umar Fārūq al-Ṭabbā', Beyrouth, Dār al-Arqam, s.d., p. 324 ; al-Hațīb, Ta'rīh Baġdād, éd. Mușțafā 'Abd al-Qādir 'Ațā, Beyrouth, Dār al-kutub al-ilmiyya, 1997, VIII, p. 490-91 ; Ibn alAtīir, al-Kāmil fì l-ta'rīh, éd. C.J. Tornberg, Brill, 1867, rééd. Beyrouth, Dār Șādir, 1982, V, p. 422. Cf. H.'A.-G/. Abū G/adda, Ahkām al-siğn wa-mu'āmalat al-suğanā', thèse dactylographiée, Tunis, Université de la Zaytūna, 1986, p. 498.

${ }^{8}$ Ibn Qutayba, 'Uyūn al-ahbār, éd. Tarwat 'Ukāša, 2 éd., Le Caire, Dār al-ma'ārif, 1969, I, p. 120.

${ }^{9}$ Ibn Manzūur, Lisān al-'arab, Beyrouth, Dār Șādir, 1997, V, p. 348 (racine q.w.m.).

${ }^{10}$ Ibn Manzūùr, Lisān al-'arab, I, p. 444 (racine ğ.l.z.).

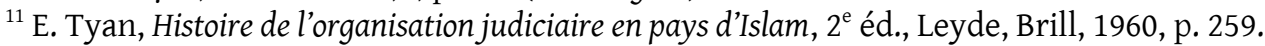

${ }^{12}$ Ibn Qutayba, 'Uyūn al-ahbār, I, p. 120 ; al-Dīnawārī, al-Ahbār al-țiwāl, p. 324 ; al-Ṭabarī, Ta'rīh, III, p. 384 ; alIșfahānī, Maqātil al-Ṭālibiyyīn, éd. Aḥmad Șaqr, Beyrouth, Mu’assasat al-álāmī li-l-maṭūūāt, 1987, p. 177.

${ }^{13}$ Wakī', Ahbār al-qudāt, II, p. 279.
} 
poste qu'Abū l-Bahtarī lui proposait à Médine ${ }^{14}$. Savant et disciple de Mālik b. Anas, il faisait partie des hautes notabilités locales ${ }^{15}$. Il est peu probable cependant que son exemple soit révélateur : lui-même savant et cadi, le gouverneur Abū l-Bahtarī voulut visiblement confier ce type de poste à des pairs - ce qui semble plutôt exceptionnel -, qui refusèrent tous en bloc. La rémunération du personnel carcéral n'est pas plus documentée. Un salaire régulier était-il assigné par l'autorité dont les gardiens relevaient ? Ou vivaient-ils de l'exploitation des prisonniers, comme ce fut le cas dans la France du XVIII ${ }^{\mathrm{e}}$ siècle ? La contribution des prisonniers à l'entretien de leurs gardiens semble avérée dans l'Occident musulman du XIV ${ }^{\mathrm{e}}$ siècle ${ }^{16}$. Les remarques d'Abū Yūsuf, qui craint les détournements de vivres par les geôliers, laisse en tout cas soupçonner certaines formes d'exploitation des détenus ${ }^{17}$.

\subsection{L'administration carcérale}

Hormis la surveillance des détenus, le personnel carcéral devait sans doute assurer des tâches administratives minimales, ne serait-ce que pour tenir le journal des entrées et des sorties. Al-Ğāhiz raconte qu'à la fin de l'époque umayyade ${ }^{18}$, le geôlier (sağğāan) de la prison de Bașra avait l'habitude de transmettre au gouverneur de la ville les noms des prisonniers décédés dans son établissement ${ }^{19}$. De fait, la gestion administrative et comptable des prisons pouvait relever de différents services, selon leur catégorie ${ }^{20}$.

La théorie juridique insiste tout d'abord sur le rôle des cadis dans l'archivage de multiples pièces administratives et judiciaires: minutes du tribunal, procès-verbaux de jugements, listes d'administrateurs de fondations pieuses et de propriétés d'orphelins, etc. ${ }^{21}$. Parmi ces documents, le hanafite al-Hasșāa (m. 261/874) insiste pour que le cadi tienne à jour une liste de détenus. Lorsqu'il décide d'emprisonner un condamné notamment pour dette -, dit-il, « le cadi écrit dans ses archives (dīwān) qu'il l'a incarcéré : “Untel fils d'Untel a été emprisonné pour Untel fils d'Untel, à qui il devait tant de dirhams, tel jour de tel mois de telle année ${ }^{22}$." " Ces archives ayant généralement disparu, la tenue effective de tels registres par les cadis demeure en partie hypothétique ${ }^{23}$. Une levée d'écrou datée de 348/959 - publiée par A. Grohmann - confirme l'existence d'une gestion administrative pointilleuse des mises en liberté, même si nulle adresse ni signature n'atteste que ce document figurait dans les archives d'un cadi ${ }^{24}$. Si les recommandations du juriste

\footnotetext{
${ }^{14}$ Wakī̄, Ahbō̄r al-quḍāt, I, p. 253.

${ }^{15}$ Ibn Abī Ḥātim al-Rāzì, al-Ğarh wa-l-ta'dīl, Beyrouth, Dār ihyā̄' al-turāt al-'arabī, 1952, VIII, p. 315 ; Ibn Hağar, Tahdīb al-tahdīib, Beyrouth, Dār al-fikr, 1984, X, p. 158 ; Wakī , Ahbār al-quḍāt, I, p. 254.

${ }^{16}$ N. Hentati, « La prison en Occident musulman médiéval », p. 168.

${ }^{17}$ A bū Yūsuf, Kitāb al-ḩarāăğ, p. 151. Sur la rémunération du personnel carcéral, voir Ph. Combessie, Sociologie de la prison, Paris, La Découverte, 2004, p. 70.

${ }^{18}$ L'anecdote concerne Bilāl b. Abī Burda (m. vers 126/744), cadi et gouverneur de Bașra, finalement arrêté et emprisonné par son successeur Yūsuf b. 'Umar al-Taqafî. H. al-Ziriklī, al-A lām, $12^{\mathrm{e}}$ éd., Beyrouth, Dār al-'ilm li1-malāyīn, 1997, II, p. 72.

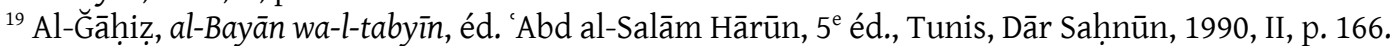

${ }^{20}$ La gestion matérielle des prisons semblait financée par l'administration centrale du califat: al-Ṣābi' inclut les dépenses d'entretien des prisonniers dans le budget du calife al-Mu'taḍid. Al-Ṣābi', al-Wuzarā' : tuhfat alumarā' fì tārīh al-wuzarā', éd. 'Abd al-Sattār Aḥmad Farāğ, s.l., Dār ihyā' al-kutub al-'arabiyya, 1958, p. 26 (nous proposons de lire « aqwāt al-muhabbasinn » - les vivres des prisonniers - à la place de « awqāt al-muhabbasīn »).

${ }^{21}$ B. Johansen, «Formes de langage et fonctions publiques : stéréotypes, témoins et offices dans la preuve par l'écrit en droit musulman », Arabica, 44 (1997), p. 347.

${ }^{22}$ Al-Hașșāf, Kitāb adab al-qāḍ̄i, p. 254.

${ }^{23}$ W.B. Hallaq prend al-Kindī (Ahbārr quḍāt Mișr, dans Kitāb al-wulāt wa-kitāb al-quḍāt, éd. R. Guest, Leyde, Brill, 1912, p. 450) pour témoin de l'enregistrement effectif des prisonniers dans le dīwān des cadis au début du $\mathrm{III}^{\mathrm{e}} / \mathrm{IX}^{\mathrm{e}}$ siècle (W.B. Hallaq, "The Qāḍ̂̀ S Dīwān (sijill) before the Ottomans », BSOAS, 61 (1998), p. 433). Le contexte de ce passage oblige néanmoins à comprendre le terme "ahbās » - sur lequel repose son interprétation - comme une référence aux « biens de mainmorte » et non aux " prisons ».

${ }^{24}$ R.G. Khoury et A. Grohmann, Chrestomathie de papyrologie arabe, Leyde, Brill, 1993, p. 148.
} 
étaient suivies, l'administration judiciaire conservait donc des registres d'écrou portant les noms des prisonniers, les dates de leur incarcération, les raisons de celle-ci et l'identité des adversaires pour lesquels l'emprisonnement avait été prononcé ${ }^{25}$. Ils permettaient des vérifications ultérieures, notamment lors de l'arrivée en poste d'un nouveau cadi : ce dernier devait s'assurer que tous les détenus étaient en prison pour une raison valable et actualiser les listes laissées par son prédécesseur ${ }^{26}$.

Les prisonniers incarcérés par le pouvoir politico-militaire semblaient quant à eux enregistrés auprès d'une administration carcérale spécifique, qui apparaît subrepticement sous le calame d'al-Ṭabarì à propos d'une émeute à Bagdad en 249/863. Alors que l'anarchie se répandait à Sāmarrā' - les militaires turcs commençant à faire et défaire les califes -, la populace ('āmma) de Bagdad se souleva aux côtés des Abnā' (les descendants des Hurāsāniens qui avaient porté les Abbassides au pouvoir en 132/750) et du corps de troupe des Šākiriyya ${ }^{27}$. Les émeutiers ouvrirent les portes des prisons, coupèrent les ponts qui traversaient le Tigre et «saccagèrent le dīwān des écrous (qișas al-muhabbasīn) : les registres (al-dafātir) furent déchirés et jetés à l'eau ${ }^{28}$. Visiblement implanté à proximité immédiate du Tigre, ce bureau (dīwān) dépendait peut-être de la police (šurța), dont le siège se trouvait à proximité des ponts ${ }^{29}$. Le pillage de cette administration et la destruction de ses archives compléta la libération des détenus par les émeutiers et compromit la poursuite ultérieure des fugitifs.

Le témoignage d'al-Hașsâ̄ et d'al-Ṭabarī laisse supposer l'existence d'un double système de gestion des prisonniers, par l'autorité judiciaire d'un côté et par une administration carcérale civile ou militaire de l'autre. Cette gestion bipartite est conforme à l'image communément admise d'une dichotomie stricte entre des prisons de cadis et des établissements relevant d'autorités politico-militaires. Pourtant, les recommandations d'alHașșāf concernant la vérification ponctuelle des listes de détenus et la nécessité d'une enquête lors de l'arrivée en poste d'un nouveau cadi offrent l'image d'un univers carcéral très marginal par rapport à la juridiction du cadi. Nulle part le juriste ne définit la relation de ce dernier à l'institution carcérale en tant que telle, ni n'évoque d'éventuels rapports hiérarchiques avec son personnel. Au-delà de la gestion des incarcérations et des mises en liberté, l'autorité respective des cadis et des autres institutions urbaines sur les établissements carcéraux mérite donc d'être examinée.

\section{L'autorité sur les prisons}

2.1. Les prisonniers du cadi : rivalités et conflits de compétences

À l'époque abbasside, les personnes emprisonnées sur décision du cadi - de manière préventive, punitive ou administrative ${ }^{30}$ - semblaient détenues dans une prison spécifique, distincte d'autres lieux de détention de la même ville. Au milieu du $\mathrm{III}^{\mathrm{e}} / \mathrm{IX}^{\mathrm{e}}$ siècle, le hanafite al-Hुașạāf (m. 261/874) évoque en effet une "prison du cadi » (habs al-qāḍ̂̀) qu'il oppose à la "prison des voleurs » (habs al-lușūṣ), sous-entendant que cette dernière ne relève pas de la même autorité ${ }^{31}$. Cette distinction, réitérée au siècle suivant par le šāfi ite Ibn al-Qāṣs (m.

\footnotetext{
${ }^{25}$ En cas de dette, l'emprisonnement ne peut être décidé que sur demande du créancier

${ }^{26}$ Al-Hुașșāf, Kitāb adab al-qā d̦ī, p. 61. Sur l'existence de registres de prisonniers au Maghreb, voir N. Hentati, «La prison en Occident musulman médiéval », p. 170.

${ }^{27}$ Voir M. Gordon, The Breaking of a Thousand Swords. A History of the Turkish Military of Samarra (A.H. 200-275/815889 C.E.), Albany, State University of New York Press, 2001, p. 91.

${ }^{28}$ Al-Tabarī, Ta'rīh, V, p. 357.

${ }^{29}$ C.E. Bosworth, « al-Rușāfa », $E I^{2}$, VIII, p. 629.

${ }^{30}$ Sur les circonstances de l'incarcération, voir I. Schneider, art. cit., p. 158 sq. Voir également infra.

${ }^{31}$ Al-Haș̣̦āf, Kitāb adab al-qāọ̄̄, p. 264. N. Hentati observe une division similaire dans le Maghreb médiéval. N. Hentati, « La prison en Occident musulman médiéval », p. 177.
} 
335/946) ${ }^{32}$ - paraît confirmée par Wakî̀ (m. 306/918) : dans ses Ahbār al-quḍāt, le cadi de Kūfa Šarīk b. 'Abd Allāh (en poste de 153/770 à 170/786 environ) parle de "sa » prison (habsi) ${ }^{33}$. L'existence de deux prisons à Kūfa est avérée un siècle plus tard: en 250/864, le révolté 'alīde Yahyā b. 'Umar pénétra dans la ville et « ouvrit [les portes] des deux prisons (al-siğnayn) et en fit sortir tous ceux qui s'y trouvaient ${ }^{34}$. Mais rien n'est ajouté quant aux autorités dont dépendaient ces deux prisons. Commentant l'existence de ces deux catégories, E. Tyan en déduit que "c'est le juge qui a l'administration ou le contrôle supérieur de la prison pour dettes ${ }^{35}$ ", affirmation implicitement acceptée par I. Schneider ${ }^{36}$. Al-Hasan 'Abd al-G/anī Abū G/adda suppose également que les prisons " civiles » où étaient incarcérés les détenus du cadi relevaient de l'autorité exclusive de ce dernier ${ }^{37}$. E. Tyan revient pourtant plus loin sur sa propre analyse et suppose que, "dès le $\mathrm{III}^{\mathrm{e}}$ s. h., sinon avant cette époque, les prisons sont confiées à la šurța ${ }^{38} »$. Ce flottement résulte, en fait, de l'ambiguïté historique des rapports entre différents pouvoirs à propos de telles prisons.

Les rares informations disponibles laissent en effet supposer une dichotomie moins stricte entre "prisons de cadis» et "prisons des voleurs»- relevant, suppose-t-on, d'autorités militaires comme le gouverneur ou le chef de la police. À Kūfa, la prison où Šarīk envoyait ses prisonniers dans la seconde moitié du $\mathrm{II}^{\mathrm{e}} / \mathrm{VIII}^{\mathrm{e}}$ siècle se trouvait dans le Dār Bilāl ${ }^{39}$, ancienne maison (ou palais) du cadi Bilāl b. Abī Burda, en poste à Kūfa de 110/728 à $120 / 738^{40}$. Ce personnage, qui fut ensuite gouverneur et chef de la police à Bașra, semblait célèbre pour son injustice et ses emprisonnements arbitraires ${ }^{41}$. Surtout, il finit lui-même emprisonné et torturé par son successeur au gouvernorat de Bașra, Yūsuf b. 'Umar alTaqafī ; ce dernier fit alors transformer la demeure de Bilāl à Kūfa en prison, ce qu'elle était encore à la fin du siècle ${ }^{42}$. Dans la première moitié du III $/ \mathrm{IX}^{\mathrm{e}}$ siècle, une autre " prison du cadi » existait peut-être à Kūfa : peu avant 235/849-50, le cadi G/assān b. Muhammad alMarwazi enferma préventivement un homme, accusé d'avoir insulté 'Alī, dans un "mağlis connu sous le nom d'al-zāwiya », mais dont on ne sait rien de plus ${ }^{43}$. À la fin du $\mathrm{II}^{\mathrm{e}} / \mathrm{VIII}^{\mathrm{e}}$ siècle, par ailleurs, les cadis de Bagdad emprisonnaient les débiteurs (al-guramá) prétendus insolvables dans le mağlis al-šurat ou Préfecture de police ${ }^{44}$. Ces rares exemples laissent deviner une certaine porosité, dans la pratique, entre les deux types de prisons évoqués par al-Hुașāâf: à Kūfa, les cadis envoyaient certains de leurs prisonniers dans un établissement fondé par un gouverneur - mais l'existence d'une autre prison est également avérée; à Bagdad, des condamnés de cadis étaient envoyés dans une prison présumée dépendre de la šurța.

À supposer que la plupart des cadis disposaient effectivement d'une prison réservée à leurs détenus, plusieurs indices laissent penser qu'il n'y exerçaient pas toujours une

\footnotetext{
${ }^{32}$ Ibn al-Qāșṣ, Adab al-qāộ̄, éd. Aḥmad Farīd al-Mazīdī, Beyrouth, Dār al-kutub al-'ilmiyya, 2007, p. 144.

${ }^{33}$ Wakī', Ahb̄ōr al-quḍāt, III, p. 151.

${ }^{34}$ Al-Ṭabarī, Ta'rīh, V, p. 360.

${ }^{35}$ E. Tyan, Histoire de l'organisation judiciaire, p. 385.

${ }^{36}$ I. Schneider, art. cit., p. 169-170.

${ }^{37}$ H.'A.-G/. Abū G/adda, Aḥkām al-siğn wa-mu'āmalat al-suğanā', p. 265, 279.

${ }^{38}$ E. Tyan, Histoire de l'organisation judiciaire, p. 613.

${ }^{39}$ Wakī, Ahbār al-quḍāt, III, p. 165.

${ }^{40}$ Ch. Pellat, Le milieu bașrien et la formation de Ğāhiz, Paris, Adrien-Maisonneuve, 1953, p. 289. Voir aussi alBalādurī, Ansāb al-ašrāf, éd. Suhayl Zakkār et Riyāọ Ziriklī, Beyrouth, Dār al-fikr, 1996, XII, p. 275-76.

${ }^{41}$ Wakīi, Ahbār al-qudāt, II, p. 36.

${ }^{42}$ Al-Ya'qūbī, Ta’rīh, éd. Ḩalīl al-Manșūr, Beyrouth, Dār al-kutub al-ilmiyya, 2002, II, p. 226-27. Sur Yūsuf b. 'Umar, voir al-Ziriklī, al-A' lām, II, p. 72.

${ }^{43}$ Wakī', Ahbār al-quḍāt, III, p. 191.

${ }^{44}$ Ibn Hallikān, Wafayāt al-a'yān, éd. Iḥsān ‘Abbās, Beyrouth, Dār Ṣādir, 1994, II, p. 199.
} 
autorité effective et que ces prisons relevaient au niveau supérieur d'un gouverneur militaire. Il semble en premier lieu que le personnel carcéral était nommé par le gouverneur de la ville ou de la province. Abū l-Bahtarī Wahb b. Wahb fut à la fois cadi et gouverneur de Médine entre 192/807 et 194/809, et il désigna alors plusieurs subordonnés responsables de secteurs sensibles de la ville, comme la prison (al-siğn) et les remparts (al-sür) ${ }^{45}$. Aucun simple cadi ne disposait, à cette époque, d'une telle autorité sur les structures défensives de sa ville: c'est donc en tant que gouverneur que Wahb avait la haute main sur ces deux secteurs et qu'il déléguait un "directeur » de la prison ${ }^{46}$. On ignore hélas si la prison de Médine était unique et accueillait à la fois les détenus du gouverneur et du cadi, ou si un établissement était réservé à ceux de ce dernier.

Plusieurs récits de conflits entre un émir et son cadi confirment que les prisons - y compris celle « du cadi » - entraient dans la sphère d'autorité des gouverneurs. À l'époque sufyānide, le cadi d'al-Kūfa Šurayh incarcéra un homme dont le gouverneur 'Ubayd Allāh b. Ziyād ${ }^{47}$ exigea ensuite la libération. "Ô émir, la prison est tienne, le directeur ('āmil) est tien, tu ordonnes et tu es obéi ", répondit Šurayh, qui refusa toutefois de faire lui-même sortir le prisonnier ${ }^{48}$. Érigé en modèle par la littérature biographique et l'adab ${ }^{49}$, Šurayh laisse ici l'image d'un cadi qui ne contrôlait pas la prison où il envoyait ses propres condamnés. La vraisemblance de la situation est corroborée par un autre récit, à peine plus tardif : à la mort du célèbre Anas b. Mālik vers 92/710, le savant Muhammad b. Sīrīn, désigné par le défunt pour effectuer la toilette mortuaire et prier sur sa dépouille, était en prison pour dette à Bașra. Bien que probablement incarcéré par le cadi, c'est auprès de l'émir de la ville qu'il obtint une permission de sortie à cet effet ${ }^{50}$. D'autres témoignages de la fin de l'époque umayyade et du début de l'époque abbasside, alors que les cadis étaient encore nommés par les gouverneurs, vont dans le même sens. En 126/744, le gouverneur de Bașra 'Abd Allāh b. Abī 'Uțmān ${ }^{51}$ fit libérer un prisonnier du cadi 'A/mir b. 'Ubayda sans le prévenir. Furieux de cette ingérence, le cadi cessa de rendre la justice et obtint finalement que le gouverneur renvoie le détenu en prison ${ }^{52}$. À Fusțāt, en 135/752-53, le gouverneur Abū 'Awn 'Abd al-Malik b. Yazīd relâcha un soldat écroué par le cadi Hayr b. Nu'aym ${ }^{53}$. Les sources insistent sur l'iniquité d'une telle ingérence et sur l'obligation qu'ont les cadis d'y résister. Mais de tels conflits révèlent surtout que, si certains prisonniers relevaient en théorie du cadi, les murs et l'administration de la prison dépendaient, de leur côté, d'un gouverneur dont les intérêts n'étaient pas toujours conciliables avec la justice ordinaire, et qui ne reconnaissait à son cadi qu'une autorité subalterne.

À partir du califat d'al-Manșūr, les cadis furent de plus en plus désignés par le calife, ce qui eut pour effet de renforcer la position locale des cadis. C'est à cette époque - est-ce un hasard ? - qu'un cadi comme Šarīk b. 'Abd Allāh se mit à évoquer « sa » prison ${ }^{54}$. Pourtant, l'autorité des cadis sur leurs prisonniers demeure aussi difficile à établir qu'à l'époque

\footnotetext{
${ }^{45}$ Wakī̄, Ahbōr al-quḍāt, I, p. 253-54.

${ }^{46}$ F. Rosenthal (The Muslim Concept of Freedom Prior the Nineteenth Century, Leyde, Brill, 1960, p. 61) déduit pourtant de l'exemple d'Abū l-Bahtarī qu'un cadi pouvait nommer un directeur de prison.

47 'Ubayd Allāh b. Ziyād b. Abī-hi (m. 67/686), gouverneur d'Iraq de 55/675 à 64/684. Ch. Pellat, op. cit, p. 277 ; al-Ziriklī, al-A 'ām, IV, p. 193.

${ }^{48}$ Wakì , Ahbār al-qudāat, II, p. 308.

${ }^{49}$ Voir H. Kohlberg, "Shurayḥ », EI $I^{2}$ IX, p. 528-29 ; M. Tillier, «L'exemplarité chez al-Tanūhīi », Arabica, 54 (2007), p. 16.

${ }^{50}$ Ibn Sa'd, al-Ṭabaqāt al-kubrā, Beyrouth, Dār Șādir, 1968, VII, p. 25.

${ }^{51}$ Gouverneur de Bașra en 126/744. Voir Halīfa b. Hayyāț, Ta'rīh, Beyrouth, Dār al-kutub al-iilmiyya, 1995, p. 241 ; Ch. Pellat, Le milieu bașrien, p. 280.

${ }^{52}$ Wakī', Ahbār al-quḍāt, II, p. 43-44.

${ }^{53}$ Al-Kindī, Ahbār quḍāt Miṣr, p. 356 ; Wak̄̄è, Ahbār al-quḍāt, III, p. 232.

${ }^{54}$ Wakī', Ahbōr al-quḍāt, III, p. 151.
} 
umayyade. Vers 146-47/764, le gouverneur de Bașra Muhammad b. Sulaymān élargit un prisonnier du cadi Sawwār b. 'Abd Allāh ${ }^{55}$. Quelques années plus tard, le même gouverneur - désormais en poste à Kūfa - fit libérer un prisonnier du cadi Šarīk b. 'Abd Allāh ${ }^{56}$, et recommença au début du règne d'al-Rašíd ${ }^{57}$. À la fin du $\mathrm{III}^{\mathrm{e}} / \mathrm{IX}^{\mathrm{e}}$ siècle, à Fustātat, Ibn Țūlūn ordonna une enquête sur les détenus de la "prison du cadi » (habs al-qāậ) et décréta leur libération après avoir fait payer leurs dettes ${ }^{58}$. De telles situations auraient été difficilement envisageables si la " prison du cadi » avait été placée sous son autorité exclusive. Tout porte à croire, au contraire, que le gouverneur la contrôlait toujours. Un cas comparable se présenta à Bagdad sous al-Rašîd: un débiteur incarcéré par le cadi d'al-Šarqiyya, Hafṣ b. G/iyāt, fut élargi par le préfet de police al-Sindī b. Šāhīk, qui tenait lieu de gouverneur de la capitale ${ }^{59}$. En 277/890, Yūsuf b. Ya qūb fut nommé président du tribunal du Redressement des torts (al-mazālim), expression de la justice califale, et al-Ṭabarī précise : "Il ordonna au préfet de police (șāhib al-šurța) de ne libérer aucun prisonnier sans l'avis de Yūsuf, et seulement après lui avoir présenté son écrou (qișaṣ) ${ }^{60}$." La précision du chroniqueur, contemporain des événements, montre que la libération d'un prisonnier relevait encore, généralement, du préfet de police - même si, en ce cas, les détenus concernés étaient peutêtre surtout les voleurs et les criminels enfermés par le șāhib al-šurța en personne. Dans la première moitié $\mathrm{du} \mathrm{IV}^{\mathrm{e}} / \mathrm{X}^{\mathrm{e}}$ siècle, Qudāma $\mathrm{b}$. Ğa far associe encore le contrôle des prisons au gouverneur militaire : c'est à lui que le calife ordonne de passer en revue les détenus et, éventuellement, de les libérer. Le cadi local ne jouerait qu'un rôle de témoin du bon déroulement de telles inspections ${ }^{61}$.

Au Maghreb, N. Hentati remarque - à la suite de R. Brunschvig - une « rivalité assez aiguë entre le qā $\bar{l} \bar{\imath}$ et le gouverneur quant à l'administration des prisons ${ }^{62}$ ». Dans l'Orient abbasside, la rivalité entre les deux institutions était moins une compétition qu'un conflit de juridictions. Au $\mathrm{II}^{\mathrm{e}} / \mathrm{VIII}^{\mathrm{e}}$ comme au $\mathrm{III}^{\mathrm{e}} / \mathrm{IX}^{\mathrm{e}}$ siècle, les "prisons du cadi ", semblaient relever administrativement $\mathrm{du}$ pouvoir politico-militaire. Comme $\mathrm{F}$. Rosenthal le pressentait déjà, toute prison appartenait d'abord et avant tout au souverain : l'éventuelle délégation d'autorité sur un établissement carcéral - même fondé par un cadi ou tout autre grand officier de l'État - pouvait à tout moment être annulée par le délégant ${ }^{63}$. La doctrine juridique, souligne I. Schneider, insiste sur le contrôle que le cadi devait exercer sur ses détenus ${ }^{64}$. Une telle insistance ne découlerait-elle pas précisément d'une situation complexe où, dans les faits, le cadi ne pouvait pas toujours vérifier ce qu'il se tramait derrière les murs de la prison? Al-Haș̣āf recommande au cadi de ne pas laisser le portier $\left(\right.$ bawwāb) de la prison libérer un détenu sans son autorisation explicite ${ }^{65}$. Cette prescription aurait peu de sens si le cadi jouissait d'une autorité indiscutée sur la prison et son personnel.

\footnotetext{
${ }^{55}$ Wakī̄ , Ahbār al-qudàt, II, p. 69.

${ }^{56}$ Wakī', Ahbār al-quḍāt, III, p. 151-152.

${ }^{57}$ Wakī', Ah̆bār al-quḍāt, II, p. 140.

${ }^{58}$ Al-Balawī, Sīrat Aḥmad b. Țūlūn, éd. Muhammad Kurd 'Alī, Le Caire, Maktabat al-țaqāfa l-dīniyya, s.d., p. 18485. Voir également Ibn Hağar, Raf al-iṣr, p. 183 (trad. Tillier, op. cit., p. 151).

${ }^{59}$ Al-Hațīb, Ta'rīh Bag̀dād, VIII, p. 187-89.

${ }^{60}$ Al-Tabarī, Ta'rīh, V, p. 598.

${ }^{61}$ Qudāma b. Ğa far, Kitāb al-ḩarāğ wa-șinā'at al-kitāba, éd. Muhammad Husayn al-Zabīdī, Bagdad, Dār al-Rašīd, 1981, p. 46.

${ }^{62}$ N. Hentati, «La prison en Occident musulman médiéval », p. 177 ; R. Brunschvig, La Berbérie orientale sous les Hafșides des origines à la fin du XV siècle, Paris, Adrien-Maisonneuve, 1940, I, p. 374-75. R. Brunschvig souligne la rivalité, au $\mathrm{XV}^{\mathrm{e}}$ siècle, entre le cadi de Kairouan et le qā'id local, disposant tous deux de leur propre prison. Suite aux plaintes du premiers, le qā’id dut fermer la sienne, jugée trop inhumaine.

${ }^{63}$ Voir F. Rosenthal, The Muslim Concept of Freedom, p. 58.

${ }^{64}$ I. Schneider, art. cit., p. 167.

${ }^{65}$ Al-Hुașșāf, Adab al-qā ḍi, p. 68.
} 
2.2. Les prisonniers du pouvoir politico-militaire: origine et localisation des établissements carcéraux

Selon la classification d'al-Hुașsāâ, une seconde catégorie de prisons - spécialement destinées aux criminels - relevait plus explicitement des institutions politico-militaires. Qualifiée de "prison des voleurs » par al-Hașșāf, elle prit plus tard le nom de " prison de la police » (habs al-ma'ūna) ${ }^{66}$, mais apparait le plus souvent dans les chroniques comme «la prison » (al-siğn, al-habs) par excellence, c'est-à-dire le lieu d'incarcération de la plupart des détenus liés à l'histoire politique de l'Islam ${ }^{67}$. Leur appellation, tout comme leur localisation, confirme souvent l'existence d'une étroite relation entre ces établissements et les autorités politico-militaires urbaines.

Dans les villes de provinces, ces prisons relevaient en général du gouverneur et faisaient partie des principales administrations mises en place dans les amșār au lendemain des conquêtes. Dès la fondation de Bașra en 17/638, la prison fut un des premiers bâtiments publics construits sur la place centrale de la ville (al-dahnā') aux côté de la mosquée, du palais de l'émir et du dīwān ${ }^{68}$. Ces prisons s'imposèrent rapidement comme des édifices stratégiques et furent souvent prises pour cibles en cas de révolte. Ainsi, lorsqu'en 64/683 éclata la seconde fitna - opposant Ibn al-Zubayr à la famille umayyade -, le gouverneur de Bașra Ibn Ziyād dut s'enfuir ; afin de maintenir l'ordre, le chef tribal al-Ahnaf b. Qays envoya des hommes tenir le trésor public (bayt al-māl), la prison et le dīwān, et fit fortifier (hașsana) ces bâtiments ${ }^{69}$. L'identification et la morphologie des prisons provinciales est souvent incertaine. À l'époque abbasside, les rares informations disponibles montrent qu'il s'agissait souvent d'anciennes demeures ou palais transformés à cet effet ${ }^{70}$. Le second gouverneur de Bașra pour les Abbasides, Sulaymān b. 'Alī (en poste de 133/751 à 139/756) ${ }^{71}$, acheta sur ses propres deniers l'ancien palais d'Ibn Ziyād et le fit convertir en prison ${ }^{72}$. À Médine, le 'alīde 'Abd Allāh b. al-Ḥasan fut incarcéré en 140/758 dans une pièce située à l'entrée du «dār Marwān ", l'ancienne demeure de Marwān b. al-Hakam ${ }^{73}$. Même si ce ne fut peut-être qu'un usage ponctuel de cette maison, la prison officielle de la ville était un édifice de même nature : al-Ṭabarī précise qu'en 145/762, lors de la révolte d'al-Nafs al-Zakiyya, la prison de Médine se trouvait dans le « dār Ibn Hišām » - probablement l'ancien palais du gouverneur Muhammad b. Hišām al-Maḩzūmī, en poste sous le calife Hišām b. 'Abd al-Malik ${ }^{74}$-, situé à

\footnotetext{
${ }^{66}$ Voir 'I.M. Šabārū, al-Qaḍ̄̄' wa-l-quḍāt fì l-islām, Beyrouth, Dār al-nahḍa l-'arabiyya, p. 69.

${ }^{67}$ Une institution comme le barìd semblait également disposer d'une prison à Kūfa à la fin du II $^{\mathrm{e}} / \mathrm{VIII}^{\mathrm{e}}$ siècle. Wakī', Ahbār al-qudāt, III, p. 165. Sur le rôle du barīd dans le transfert de prisonniers, voir par ailleurs A.J. Silverstein, Postal Systems in the Pre-Modern Islamic World, New York, Cambridge University Press, 2007, p. 56, 99. Al-Ḥasan 'Abd al-G/ānī Abū G/adda (Aḥkām al-siğn wa-mu'āmalat al-suğanā', p. 266) différencie quant à lui les «prisons politiques » des « prisons pour criminels ». Cette classification ne repose néanmoins sur aucun indice textuel : tout porte à croire, au contraire, qu'une grande prison «politique » comme le Muṭbaq accueillait aussi des populations criminelles (voir infra).

${ }^{68}$ Al-Balādurī, Futūh al-buldān, Beyrouth, Dār al-kutub al-ilmiyya, 2000, p. 208.

${ }^{69}$ Halīfa b. Hayyāt, Ta'rīh, p. 160. Cf. C.F. Robinson, «'Ubayd Allāh b. Ziyād », EI $I^{2}$, X, p. 763

${ }^{70}$ Sur l'origine «domestique » des prisons au début de l'Islam, voir l'article à paraitre de Sean W. Anthony, "The Domestic Origins of Imprisonment: An Inquiry into an Early Islamic Institution ». Selon A. Northedge (The Historical Topography of Samarra, British School of Archaeology in Iraq - Fondation Max van Berchem, Londres, 2005, p. 114), la "grande prison » de Sāmarrā' n'apparaît pas comme un édifice spécifiquement construit à cet effet, mais plutôt comme le réemploi d'un ancien bâtiment.

${ }^{71}$ Voir Ch. Pellat, Le milieu bașrien, p. 280.

${ }^{72}$ Al-Balādurī, Futūḥ al-buldān, p. 221.

${ }^{73}$ Al-Ișfahānī, Maqātil al-Ṭālibiyyīn, p. 193.

${ }^{74}$ Cf. Halîfa b. Hayyāt, Ta'rīh, p. 232.
} 
côté de la musallā des funérailles, côté qibla ${ }^{75}$. La seule prison connue de Fusțāt fut bâtie vers 212/827 par le gouverneur 'İsā b. Yazīd al-Ğulūdī sur les ruines d'un ancien palais appelé " qașr Māriya " $^{76}$. Les palais ou demeures convertis en prisons avaient souvent appartenu à d'anciens gouverneurs locaux, et la conversion avait elle-même été effectuée par un de leurs successeurs.

Dans la capitale abbasside, des espaces à vocation non carcérale furent parfois utilisés comme lieu d'enfermement, tout particulièrement lorsqu'ils s'avéraient plus adaptés au but recherché - qui n'était pas toujours la simple privation de liberté. Le calife al-Manșūr fit ainsi emprisonner un fonctionnaire dans le Dār al-'ad̄āb (le «Palais des supplices »). Accusé de détournements de fonds, l'homme fut effectivement torturé dans cette salle d'interrogatoire située à proximité de la prison politique par excellence, le Muțbaq ${ }^{77}$. Le rebelle abbasside 'Abd Allāh b. 'Alī mourut en 147/764 dans l'effondrement programmé d'une maison (bayt) qui lui servait de prison ${ }^{78}$. Les demeures privées d'officiers militaires accueillirent aussi des prisonniers: ayant eu vent d'un plan d'évasion, al-Mahdī fit transférer al-Ḥasan b. Ibrāhīm - incarcéré dans le Muṭbaq depuis al-Manșūr - chez son mawlā Nuṣayr al-Wașîf, possesseur d'une qațî́a sur la rive orientale de Bagdad ${ }^{79}$; cette précaution n'empêcha pas le détenu de finalement s'évader ${ }^{80}$. Plusieurs palais servirent de prisons dorées au $\mathrm{IV}^{\mathrm{e}} / \mathrm{X}^{\mathrm{e}}$ siècle : sur la rive occidentale, au Nord de Madīnat al-Manșūr, le Ḥarīm des Ṭāhirides - ancienne résidence des gouverneurs de Bagdad - accueillit plusieurs califes déposés, tels al-Muttaqī et al-Qāhir ${ }^{81}$; le somptueux "Palais de l'arbre " (dār alšağara), bâti sous al-Muqtadir, servit plus tard à maintenir en résidence surveillée les proches de certains califes ${ }^{82}$. Même des bâtiments administratifs accueillirent des prisonniers: sous al-Mutawakkil, le secrétaire Nağāh b. Salama fut emprisonné dans le Dīwān du harāăg à Sāmarrā' ${ }^{83}$. D'autres endroits servirent de prison afin d'humilier un détenu : d'après Ibn 'Abd Rabbih, al-Mahdī fit emprisonner le poète Abū Dulāma dans un poulailler (bayt al-dağăğ), car il avait été trouvé ivre alors que le calife venait de lui décerner un taylasān honorifique ${ }^{84}$. Lors de la mihnna, Ibn Hanbal fut peut-être incarcéré un temps dans l'écurie (iștabl) de Muhammad b. Ibrāhīm, neveu du Préfet de police de Bagdad, dans une maison du Dār 'Umāra ${ }^{85}$.

\footnotetext{
${ }^{75}$ Al-Ṭabarī, Ta'rīh, IV, p. 423, 425, 433, 438, 444. Al-Balādurī mentionne encore une "prison d'Ibn Sibā'`», devant son nom à un opposant du Prophète que Hamza tua lors de la bataille d'Uhud. Rien de plus n'est connu à son sujet, et peut-être ne s'agit-il que d'un lieu-dit. Al-Balādurī, Futūḥ al-buldān, p. 38. Voir également Yāqūt, Mu'ğam al-buldān, Beyrouth, Dār Bayrūt, 1988, III, p. 193.

${ }^{76} \mathrm{Ibn}$ 'Abd al-Hakam, Futūh Mișr wa-ahbāru-hā, éd. Ch. C. Torrey, Le Caire, Maktabat Madbūlī, 1999, p. 112. Sur al-Ğulūdī, voir al-Kindī, Ahbōar quḍāt Mișr, p. 184-85. Cf. Ș.A. al-'Alī, Ahl al-Fusțāt, Beyrouth, Šarikat al-mațbū'āt, 2000, p. 102.

${ }^{77}$ Al-Balādurī, Ansā̄b al-ašrāf, éd. 'Abd al-'Azīz al-Dūrī, Beyrouth, Franz Steiner Verlag, 1978, III, p. 260. Sur la vocalisation de «Muṭbaq" (parfois transcrit « Maṭbaq»), voir R. Dozy, Supplément aux dictionnaires arabes, Leyde, Brill, 1881, II, p. 26.

${ }^{78}$ Al-Ṭabarī, Ta'rīh, IV, p. 483.

${ }^{79}$ Al-Ya'qūbī, Kitāb al-buldān, éd. M.J. de Goeje, Leyde, Brill, 1892, p. 252.

${ }^{80}$ Al-Tabarī, Ta'rīh, IV, p. 549.

${ }^{81}$ G. Le Strange, Baghdad During the Abbasid Caliphate, Oxford, Clarendon Press, 1900, p. 119, 120 ; J. Lassner, The Topography of Baghdad in the Early Middle Ages, Detroit, Wayne State University Press, 1970, p. 251-52.

${ }^{82}$ Ibid., p. 258

${ }^{83}$ Al-Tabarī, Ta'rīh, V, p. 330. Voir A. Northedge, The Historical Topography of Samarra, p. 110, 125. Il semble par ailleurs qu'à Constantinople, le Praetorium servait de lieu d'incarcération de prisonniers arabes. M. Canard, "Les expéditions des Arabes contre Constantinople », p. 97.

${ }^{84} \mathrm{Ibn}$ 'Abd Rabbih, al-'Iqd al-farīd, éd. A. Amīn, A. al-Zīn et I. al-Abyārī, Beyrouth, Dār al-Andalus, 1996, I, p. 220. Sur ce poète, voir J. Horovitz, « Abū Dulāma », EI $I^{2}$, I, p. 116

${ }^{85}$ Ibn Ab̄̄ Ya lā, Ṭabaqāat al-ḥanābila, Beyrouth, Dār al-márifa, s.d., II, p. 5 ; al-Subkī, Ṭabaqāt al-šāi iyya l-kubrā, éd. 'Abd al-Fatāh Muhammad al-Ḥulū et Maḥmūd Muhammad al-Ṭanāḥ̄, al-Ğ̄̄za, Hağar li-l-țibā'a wa-l-našr, 1992, II, p. 44. Dār 'Umāra est un quartier du Côté Ouest de Bagdad, jouxtant le rabad Abī Hanīfa et le rabaḍ
} 
À ces lieux d'incarcération occasionnels s'ajoutent les prisons bagdadiennes officielles. Elles furent réparties dans divers quartiers au gré de la croissance urbaine. Le Côté Ouest, le premier à se développer, fut longtemps le lieu d'implantation des principales prisons. Dans la lignée de la tradition antérieure, le premier palais califal - Bāb al-dahab, au centre de Madīnat al-Manșūr (la "Ville ronde») - était lui-même doté d'une prison (1) ${ }^{86}$ : un Umayyade réfugié au Yémen puis capturé et envoyé à al-Manșūr fut emprisonné dans «le palais » (al-qașr) ${ }^{87}$. L'association d'une prison à la résidence califale se poursuivit longtemps : à Marw, al-Ma'mūn enferma son général Ḥarțama b. A'yan dans une "qubba » de son palais ${ }^{88}$, et le Dār al-'āmma de Sāmarrā' sembla à son tour abriter une prison ${ }^{89}$. Au bout de quelques décennies à peine, les califes délaissèrent Madīnat al-Manșūr au profit de nouveaux palais du Côté Est. La "Ville ronde » demeura néanmoins longtemps un lieu de détention privilégié, peut-être en vertu de son caractère enclos et fortifié: jusqu'en 307/919-20 au moins, ses quatre portes de fer pouvaient être fermées en cas d'alerte, ce qui permit de reprendre des prisonniers évadés ${ }^{90}$. Le «Palais d'or » (qașr al-dahab) servait encore de prison en 235/849-50 et en 254/868 ${ }^{91}$. Madīnat al-Manșūr accueillait également la fameuse prison du Muṭbaq (2), sur laquelle nous allons revenir plus longuement. La « prison des zindīqs » (habs al-zanādiqa) qu'al-Ṭabarī mentionne sous al-Amīn, réservée aux personnes accusées de crypto-manichéisme comme Abū Nuwās ${ }^{92}$, n'était peut-être pas une prison à part entière, mais une section spécifique à l'intérieur du Muțbaq ${ }^{93}$.

C'est également sur le Côté Ouest de Bagdad que se trouvait la prison de Bāb al-šām (3) : elle fut citée pour la première fois en $235 / 849$, lorsqu'un incendie la ravagea, mais existait peut-être depuis al-Manșūr ${ }^{94}$. Située en face de Bāb al-Šām (la Porte de Syrie) et non loin de la qațía d'al-Faḍl b. Sulaymān al-Ṭūsī - dans un faubourg de Madīnat al-Manșūr - ${ }^{95}$, elle accueillait surtout des criminels (așhāb al-ğarẳim) : tous s'évadèrent en 255/869, à la faveur d'une révolte urbaine au cours de laquelle la porte de la prison fut enfoncée, en ne laissant sur place que les malades et les hommes trop affaiblis. Comme les forces armées ne bougeaient pas, on finit par murer la porte de la prison avec des briques crues et de la terre ${ }^{96}$. La «prison d'Ishạā b. Ibrāhīm b. Muș'ab » (4), citée en l'an 234/848, devait son nom

\footnotetext{
'Uțān b. Nahīk. Yāqūt, Mu'ğam al-buldān, II, p. 422. Șālih b. Ahmad b. Hanbal évoque simplement « une maison louée pour lui » dans le même quartier. Șālị b. Aḥmad b. Hanbal, Sirrat al-imām Ahmad b. Hanbal, éd. Muhammad al-Zağlī, Beyrouth - Damas - Amman, al-Maktab al-islāmī, 1997, p. 34.

${ }^{86}$ Le palais de Mu'āwiya à Damas incluait déjà une prison. C.F. Robinson, 'Abd al-Malik, Oxford, Oneworld, 2005, p. 47. Pour un aperçu des principales prisons à l'époque umayyade, voir W. al-Ṣamad, al-Suğūn wa-ataru-hā fi làdāb al-'arabiyya, p. 85 sq.

${ }^{87}$ Al-Balādurī, Ansāb al-ašrāf, éd. Suhayl Zakkār et Riyād Ziriklī, Beyrouth, Dār al-fikr, 1996, IX, p. 326.

${ }^{88}$ Ibn Qutayba, Kitāb al-ma'āirif, éd. Tarwat 'Ukāšă, $2^{2}$ éd., Le Caire, Dār al-ma'ārif, 1969, p. 389.

${ }^{89}$ Al-Tabarī, Ta'rîh, V, p. 383. En 225/839-40, une prison fut par ailleurs construite pour al-Afšinn dans le palais d'al-Ğawsaq (al-Țabarī, Ta'rihh, V, p. 263). Voir A. Northedge, The Historical Topography of Samarra, p. 136, 143.

${ }^{90}$ Al-Hațīb, Ta'rịh Baǵdād, I, p. 75-76. Voir également al-Tabarī (Ta'rīh, V, p. 592), qui signale un événement similaire en 272/885. Cf. G. Le Strange, Baghdad During the Abbasid Caliphate, p. 44 ; Ș.A. al-'Alī, Baǵdād Madīnat alSalām. Al-Ğānib al-ġarbī, Bagdad, al-Mağma' al-'ilmī al-'irāqī, 1985, I, p. 311-12 ; J. Lassner, The Topography of Baghdad, p. 55, 243.

${ }^{91} \mathrm{La}$ famille d'Ibn al-Ba īt y fut enfermée (sur ce personnage, voir V. Minorsky et C.E. Bosworth, « Marand», $E I^{2}$, VI, p. 504), et al-Mu'tazz y envoya plus tard des prisonniers. Al-Ṭabarī, Ta'rīh, V, p. 304, 426. Sur ce quartier de Bagdad, voir G. Le Strange, Baghdad During the Abbasid Caliphate, p. 31.

${ }^{92} \mathrm{Al}$-Tabarī, Ta'rīh, V, p. 115.

${ }^{93}$ C'est l'interprétation de M. Chokr, Zandaqa et zindīgs en Islam au second siècle de l'hégire, Damas, IFD, 1993, p. 23.

${ }^{94} \mathrm{Ibn}$ al-Ğawzī, al-Muntazam fì tawārīh al-mulūk wa-l-umam, éd. Suhayl Zakkār, Beyrouth, Dār al-fikr, 1995, VI, p. 436 ; G. Le Strange, Baghdad During the Abbasid Caliphate, p. 130-31. Voir Ș.A. al-'Alī, Bag̀dād Madīnat al-Salām, I, p. 334.

${ }^{95} \mathrm{Al}-Y a$ a qūbī, Kitāb al-buldān, p. 248.

${ }^{96} \mathrm{Al}$-Tabarī, Ta'rīh, V, p. 437.
} 
au șāhib al-šurța qui gouverna la ville d'al-Ma'mūn à al-Mutawakkil ${ }^{97}$ : comme le palais de ce dernier, elle était probablement implantée près du Tigre, et se confondait peut-être avec le siège de la police, à l'extrémité occidentale du pont principal ${ }^{98}$. Une cinquième prison fut bâtie au Nord de Madīnat al-Manșūr à une époque indéterminée : cette " prison du peuple » (siğn al-'āmma ou habs al-'āmma) (5), située dans la rue (darb) al-Mawșiliyya, dans le quartier al-Baġawiyīn, accueillit Ibn Hanbal sous al-Mu'tașim ${ }^{99}$. Une "prison nouvelle » (al-siğn alğadìd) est enfin signalée à partir de 289/902 (6) : elle était vraisemblablement située à proximité du Tigre, en aval du Huld, à l'emplacement de l'ancien palais d'Umm Ğafar (épouse d'al-Rašīd et mère d'al-Amīn) appelé al-Qarār: al-Mutawakkil avait concédé ce palais au șāhib al-šurța Muhammad b. 'Abd Allāh b. Țāhir ${ }^{100}$, et une de ses ailes fut plus tard transformée en prison ${ }^{101}$. Hormis les populations criminelles qui y étaient incarcérées, elle accueillit des prisonniers politiques : des comploteurs y furent envoyés en $292 / 905^{102}$. Une mutinerie éclata dans la prison en 306/918, au cours de laquelle les détenus escaladèrent les murailles. Nizār b. Muhammad, le Préfet de police, envoya des cavaliers contre eux, et le calme revint après qu'il eut tué un des révoltés et qu'il eut lancé sa tête à ses compagnons ${ }^{103}$.

Le Côté Est de Bagdad accueillit également des prisons. Celle de "Nașr b. Mālik » (7), mentionnée pour la première fois en l'an 166/782-83, devait son nom à Nașr b. Mālik alHuzāī (m. 161/778), Préfet de police pour al-Mahdī ${ }^{104}$. Cette prison, où fut enfermé le vizir de tendance chiite Ya'qūb b. Dā'ūd ${ }^{105}$, se trouvait peut-être à al-Rușāfa - un marché y conserva longtemps le nom de Nașr ${ }^{106}$. Elle existait encore un siècle plus tard; selon alTabarī, qui la mentionne dans les événements de 249/863, elle accueillait surtout des populations criminelles venues de la partie orientale de l'empire : « raclures » du Hurāsān, bandits (sa'âlīk) du Ğibāl, mais aussi des révoltés divers (muhammira) ${ }^{107}$. À la même époque, d'autres prisonniers étaient incarcérés au pont (al-qanțara), à Bāb al-Ğisr (8) : cette porte fermait l'extrémité orientale du Haut Pont reliant al-Harbiyya (Côté Ouest) et al-Ruṣāfa (Côté Est) ${ }^{108}$.

\subsection{Le Mutbaq}

La plus célèbre prison de Bagdad - et la mieux documentée - était sans conteste le Muṭaq. Cité dès 145/762-63 par al-Ṭabarī, l'année même de la fondation de Bagdad ${ }^{109}$, il fut

\footnotetext{
${ }^{97}$ Al-Ṭabarī, Ta’rīh, V, p. 299. Cf. al-Ziriklî, al-A lām, I, p. 292.

${ }^{98}$ Cf. Ibn Ṭayfūr, Kitāb Bağdād, éd. Muhammad Zāhid b. al-Ḥasan al-Kawțarī, s.l., Maktab našr al-țaqāfa alislāmiyya, 1949, p. 42. Voir Le Strange, Baghdad During the Abbasid Caliphate, Carte V, n 7 ; J. Lassner, The Topography of Baghdad, p. 150-51.

${ }^{99}$ Ṣālih b. Ahmad b. Hanbal, Sīrat al-imām Aḥmad b. Hanbal, p. 34 ; al-Subkī, Ṭabaqāt al-šāfi ìyya l-kubrāa, II, p. 44. Ce quartier est le plus souvent appelé « al-Baġiyīn ». Il fut habité par les descendants d'un certain Hafș b. 'Uțān, dont le palais passa ensuite aux Țāhirides. Al-Bagiiyīn se situe dans quartier du Šāri', faubourg est d'alHarbiyya, entre le pont principal de bateaux et le Haut pont. G. Le Strange, Baghdad During the Abbasid Caliphate, p. 107-108 ; S.A. al-'Alī, Bag̀dād Madīnat al-Salām, II, p. 190.

${ }^{100}$ Sur ce personnage, voir M. Kaabi, Les Țāhirides au Hurāsān et en Iraq (III İe H./IX ème J.-C.), Tunis, 1983, p. 331.

${ }^{101}$ Al-Hुațịb, Ta'rīh Baġdād, I, p. 87. Voir G. Le Strange, Baghdad During the Abbasid Caliphate, p. 102-103 ; Ș.A. al'Alī, Bä́d̄̄d Madīnat al-Salām, I, p. 352, 354.

${ }^{102}$ Al-Tabarī, Ta'rīh, V, p. 640, 657.

${ }^{103} \mathrm{Ibn}$ al-Ğawzī, al-Muntazam, VIII, p. 11.

${ }^{104} \mathrm{Cf}$. al-Ziriklī, al-A' $\mathrm{làm}$, VIII, p. 27.

${ }^{105}$ Al-Ṭabarī, Ta'rīh, IV, p. 578. Voir S. Moscati, « Abū ‘Abd Allāh Ya ḳūb b. Dā'ūd », EI $I^{2}$ I, p. 103.

${ }^{106}$ Ce marché se situait sur le canal al-Mahdī, juste en dessous du quartier grec, du Côté Est. Voir G. Le Strange, Baghdad During the Abbasid Caliphate, p. 214, 215.

${ }^{107}$ Al-Ṭabarī, Ta'rīh, V, p. 357.

${ }^{108}$ Al-Ṭabarī, Ta'rīh, V, p. 357. Voir G. Le Strange, Baghdad During the Abbasid Caliphate, p. 178, 198.

${ }^{109}$ Al-Ṭabarī, Ta'rīh, IV, p. 453.
} 
implanté à l'intérieur de la «Ville ronde » d'al-Manșūr. Le Strange le localise à l'extrémité du quart Sud, entre les portes de Bașra et de Kūfa ${ }^{110}$. Selon al-Ya qūbī, il se dressait dans une rue à laquelle il donna son nom (sikkat al-Muțbaq, "rue du Mutbaq ») : "dans cette rue se trouve la grande prison (al-habs al-a'zam) que l'on appelle le Mutbaq: il s'agit d'une construction solide, aux murailles inébranlables ", affirmait-il dans la seconde moitié du $\mathrm{III}^{\mathrm{e}} / \mathrm{IX}^{\mathrm{e}}$ siècle ${ }^{111}$.

Cette prison accueillit peut-être, au fil des années, divers genres de criminels ${ }^{112}$. Mais à l'origine au moins, elle semblait destinée à des détenus politiques ayant participé à des complots ou à des révoltes. Sous al-Manșūr, un jeune complice des révoltés hasanides Muhammad et Ibrāhīm b. 'Abd Allāh y fut jeté après avoir échappé de justesse à la décapitation ${ }^{113}$, et de nombreux 'Alīdes y furent transférés ${ }^{114}$. Al-Mahdī y envoya 'Abd Allāh b. Marwān - un Umayyade réfugié au Yémen puis capturé par le gouverneur de cette province -, qu'il ne pouvait exécuter sans provoquer de remous ${ }^{115}$. De même, en 164/78081, le calife voulut faire décapiter un général vaincu par les Byzantins et l'emprisonna finalement dans le Muțbaq suite à une intercession en sa faveur ${ }^{116}$. Deux ans plus tard, il dit à son vizir Ya'qūb b. Dā'ūd, soupçonné de sentiments pro-'alīdes : "Ton sang me serait licite si je souhaitais le verser! Qu'on l'enferme dans le Muṭbaq ${ }^{117}$ ! » L'incarcération s'y substituait ainsi à une condamnation à mort, lorsque la culpabilité n'était pas établie avec certitude ou qu'une exécution eût été politiquement mal venue. De fait, le condamné était comme enterré vivant, dans des conditions de survie extrêmes. La principale description vient d'al-Ṭabarī, qui prête ces paroles à Ya'qūb b. Dā'ūd :

Je fus donc emprisonné dans le Muṭbaq. On m'y choisit un puits (bi'r) et l'on m'y descendit. J'y demeurai un temps infini, sans pouvoir compter les jours. Je perdis la vue et mes cheveux poussèrent au point qu'ils pendaient comme ceux d'une bête. J'étais dans cet état lorsque l'on m'appela, et l'on me conduisit dans un lieu inconnu. On ne tarda pas à me dire: "Salue le Commandeur des croyants!» Je saluai. "Quel Commandeur des croyants suis-je?» demanda mon interlocuteur. - «Al-Mahdī», répondis-je. - «Allāh ait son âme!» dit-il. - «Al-Hādī, alors?» - «Allāh ait son âme!» répondit-il. - «Al-Rašīid, donc?» demandai-je. - « Oui », répondit-il. - « Je ne doute pas que le Commandeur des croyants a pris connaissance de mon histoire et de ma maladie : il sait que je n'en ai plus pour longtemps ", déclarai-je. - "Bien sûr, répondit-il. Je sais tout cela: le Commandeur des croyants a été informé. Demande ce que tu souhaites. »- " Je désire demeurer à La Mecque », répondis-je. - « Nous te l'accordons. Y a-t-il autre chose ? »- « Je n'ai pas d'autre désir. »- «Qu'il en soit donc ainsi. » Je m'en allai et tournai mon visage vers La Mecque.

Son fils dit : Il demeura à La Mecque et mourut peu de temps après ${ }^{118}$.

Le Mutbaq n'apparaît pas comme un simple cachot ${ }^{119}$, mais comme une prison abritant, derrière ses hauts murs, une série de puits où les détenus étaient descendus au bout d'une

\footnotetext{
${ }^{110}$ G. Le Strange, Baghdad During the Abbasid Caliphate, p. 27.

${ }^{111}$ Al-Ya'qūbī, Kitāb al-buldān, p. 240.

${ }^{112}$ Al-Ṭabarī évoque ainsi deux « mauvais garçons » (šutțār) qui y furent emprisonnés en 210/825-26. Al-Ṭabarī, Ta'rih, V, p. 169.

${ }^{113}$ Al-Ṭabarī, Ta'rīh, IV, p. 453 ; voir également al-Ṭabarī, Ta’rīh, IV, p. 574. Un autre complice de Muhammad b. 'Abd Allāh, 'Abd Allāh b. 'Umar (descendant de 'Umar b. al-Ḩațțāb, m. 171 ou 172/787-89), fut également incarcéré dans le Muțaq. Al-Hațīb, Ta'rīh Bag̀dād, X, p. 19.

${ }^{114}$ Voir notamment al-Ișfahānī, Maqātil al-Ṭālibiyīn, p. 180 ; al-Hुațīb, Ta’rīh Baġdād, VII, p. 150 ; IX, p. 433 ;

${ }^{115}$ Al-Balādurī, Ansāb al-ašrāf, IX, p. 326.

${ }^{116}$ Al-Ṭabarī, Ta'rīh, IV, p. 570 ; Halīfa b. Hayyāț, Ta'rīh, p. 288.

${ }^{117}$ Al-Ṭabarī, Ta'rīh, IV, p. 577 ; al-Hुațīb, Ta'rīh Bag̉dād, XIV, p. 264 ; Ibn Hallikān, Wafayāt al-a'yān, VII, p. 24. Voir T. El-Hibri, Reinterpreting Islamic Historiography. Hārūn al-Rashīd and the Narrative of the 'Abbāsid Caliphate, Cambridge, Cambridge University Press, 1999, p. 48.

${ }^{118}$ Al-Țabarī, Ta'rīh, IV, p. 577.

${ }^{119}$ Cf. E. Tyan, Institutions du droit public musulman, I, Le Califat, Paris, Recueil Sirey, 1954, p. 414.
} 
corde ${ }^{120}$. Ils y vivaient dans un noir absolu et perdaient toute notion du temps. D'autres récits viennent le confirmer : selon al-Ișfahānī, des 'Alīdes incarcérés dans le Muṭbaq sous al-Manșūr ne pouvaient distinguer le jour et la nuit ni connaître les heures de prière. Leur seul repère temporel était fourni par l'un d'entre eux - 'Alī b. al-Hasan b. al-Hasan, mort en prison en 146/763 -, qui récitait le Coran en boucle ${ }^{121}$. Cette prison était donc une oubliette au sens propre, où le calife se débarrassait de ceux dont il ne souhaitait plus jamais entendre parler. Son appellation était symbolique: dérivé de la racine t..b.q., impliquant l'idée de "couvrir, recouvrir, fermer ${ }^{122}$ ", le Mutbaq s'apparentait à un "couvercle " se refermant à tout jamais sur le détenu. Sorte de Bastille, il servait à impressionner les masses et alimentait la peur du pouvoir : lorsqu'en 236/850-51 al-Mutawakkil fit raser le tombeau d'al-Husayn à Karbalā' et interdit de s'y rendre, un subordonné du Préfet de police cria aux alentours: "Toute personne qui sera trouvée auprès de sa tombe après trois [jours] sera envoyé au Mutbaq! »'annonce suffit pour que les chiites s'enfuient et ne reviennent plus de sitôt ${ }^{123}$. Mais si les oubliettes du Mutbaq étaient aptes à frapper les esprits, des formes d'emprisonnement moins sévères y semblaient pratiquées en parallèle : en 210/825-26, une mutinerie s'y déclara, au cours de laquelle des détenus barricadèrent la porte principale de la prison ${ }^{124}$ : visiblement ceux-ci ne croupissaient pas au fond de puits.

Le Muţbaq fut la principale prison de Bagdad pendant plus d'un siècle. Les califes alRašīd et al-Ma'mūn y envoyèrent des prisonniers politiques comme le prédicateur Muhammad b. al-Layt ou le conspirateur Ibn 'A/'iša, ou encore des révoltés 'alīdes ${ }^{125}$. Il continua à être utilisé comme prison politique lorsque les califes partirent à Sāmarrā' : en 231/845-46, al-Wātiq y envoya un rebelle hāriğite ${ }^{126}$; sous al-Mutawakkil, le médecin Bahtišū et le soufi Dū l-Nūn y furent incarcérés ${ }^{127}$; dix membres de la famille de l'officier Bug̉ā al-Šarabī y furent emprisonnés en $254 / 868$, sous al-Mu'tazz ${ }^{128}$; des 'Alīdes y furent enfin conduits à plusieurs reprises jusqu'au règne d'al-Mu'tamid ${ }^{129}$. Les mentions du Muṭaq disparaissent après 272/885. Le retour d'al-Mu'tadid à Bagdad en 279/892 provoqua une grande réorganisation de la capitale autour d'un nouveau centre, le Dār al-ḩilāfa, sur la rive orientale du Tigre ${ }^{130}$. L'ancienne ville d'al-Manșūr, affectée par les destructions et les transformations, n'était visiblement plus apte à accueillir la principale prison : peut-être le Muṭbaq fut-il alors remplacé par la "Prison nouvelle» (al-siğn al-ğadīd, voir supra) apparaissant dans les sources une décennie plus tard.

Le Muṭbaq de Bagdad servit néanmoins de modèle. À Sāmarrā', en 227/841-42, alMu'tașim fit enfermer deux révoltés syriens - Abū Ḥarb al-Mubarqa' et Ibn Bayhas - dans un muțbaq ${ }^{131}$. La dénomination fut reprise dans d'autres provinces, notamment en Égypte : en 270/884, Ibn Ṭūlūn jeta un chrétien dans le muțbaq ${ }^{132}$ et en 304/916-17, un brigand 'alīde y

\footnotetext{
${ }^{120}$ Cette morphologie est confirmé par un récit d'al-Balādurī, dans lequel al-Ma'mūn se rend « à la porte » du Muțbaq pour se faire remettre un prisonnier. Al-Balādurī, Ansāb al-ašrāf, III, p. 127.

${ }^{121}$ Al-Ișfahānī, Maqātil al-Ṭālibiyyīn, p. 176-77.

${ }^{122}$ A. de B. Kazimirski, Dictionnaire arabe-français, Paris, Maisonneuve, 1860, II, p. 55.

${ }^{123}$ Al-Tabarī, Ta'rīh, V, p. 312.

${ }^{124}$ Al-Țabarī, Ta'rîh, V, p. 169.

${ }^{125}$ Al-Ṭabarī, Ta’rīh, IV, p. 657 ; V, p. 168 ; al-Ișfahānī, Maqātil al-Ṭālibiyyīn, p. 405. Parmi les détenus du Muṭbaq sous al-Rašīd figure également Ibrāhīm al-Nadīm al-Mawșilī (Ibn Hallikān, Wafayāt al-a yān, I, p. 43).

${ }^{126}$ Al-Ṭabarī, Ta'rìh, V, p. 284.

${ }^{127}$ Al-Tabarī, Ta'rīh, V, p. 331 ; Ibn Hallikān, Wafayāt al-áyān, I, p. 316.

${ }^{128}$ Al-Ṭabarī, Ta'rīh, V, p. 426.

${ }^{129}$ Al-Ṭabarī, Ta'rîh, V, p. 310, 312, 592 ; al-Mas'ūdī, Murūğ al-dahab, Beyrouth, Dār al-andalus, 1996, IV, p. 176.

${ }^{130}$ Voir D. Sourdel, L'État impérial des califes abbassides, Paris, PUF, 1999, p. 127.

${ }^{131}$ Al-Ṭabarī, Ta'rīh, V, p. 270. Sur ces personnages, voir P.M. Cobb, White Banners, Albany, State University of New York Press, 2001, p. 116.

${ }^{132}$ Ibn Hağar, Raf al-ișr 'an quḍāt Miṣr, éd. 'Alī Muhammad 'Umar, Le Caire, Maktabat al-Ḩānğ̄̄, 1998, p. 16 (trad. M. Tillier, Vies des cadis de Miṣr, Le Caire, IFAO, 2002, p. 69).
} 
fut incarcéré ${ }^{133}$. S'agissait-il de prisons portant le même nom? La principale prison, à Sāmarrā', était plutôt connue comme " la Grande prison » (al-habs al-kabir), le long de l'axe central ${ }^{134}$. Peut-être l'image la plus emblématique du Muṭbaq de Bagdad - celle de ses oubliettes - était-elle déjà en train de commuer le «muțbaq " en nom commun, désignant un genre de « prison souterraine » désormais en usage dans tous les centres de pouvoir ${ }^{135}$.

\section{Conclusion}

La dichotomie théorique entre une "prison du cadi», accueillant en majorité des débiteurs insolvables, et une "prison des voleurs" surtout destinée aux détenus des autorités politico-militaires, ne reflète qu'imparfaitement l'autorité hiérarchique réelle sur les établissements carcéraux de l'Iraq abbasside. Des individus très respectables étaient emprisonnés pour dettes, et leur isolement vis-à-vis de populations criminelles peu recommandables fut probablement très tôt pratiqué. Comme les cadis traitaient majoritairement des affaires civiles - la poursuite des criminels incombant à la šurța -, les prisons où ils envoyaient leurs prévenus ou leurs condamnés étaient étroitement associées à leur juridiction. Pour autant, rien n'indique que les murs de «leur» prison ni son personnel relevaient de leur autorité : le silence des manuels d'adab al-qāḍ̄ sur ce point est tout à fait révélateur. Au contraire, malgré une relative incertitude sur les types de prison concernés, de multiples indices textuels laissent supposer que la plupart des établissements étaient hiérarchiquement placés sous l'autorité du pouvoir politico-militaire. Une telle situation provoquait régulièrement des conflits de compétences dans les "prisons du cadi » : dans les villes de provinces, les bâtiments et le personnel relevaient du gouverneur et le cadi ne pouvait facilement imposer sa voix quant au sort des détenus qu'il y avait envoyés.

La localisation et la toponymie des prisons bagdadiennes reflètent pour leur part le lien étroit qu'elles entretenaient avec les autorités militaires de la capitale. Sous al-Manșūr, le Muṭbaq et « les prisons » en général étaient placées sous l'autorité d'Abū l-'Abbās al-Faḍl b. Sulaymān al-Ṭūsī, gouverneur de la « Ville ronde ${ }^{136}$. Le șāhib al-šurța de Bagdad y assumait le rôle de gouverneur; deux prisons au moins prirent le nom des Préfets de police Ishāa $b$. Ibrāhīm b. Mușab et Nașr b. Mālik, et une troisième - la " prison nouvelle » - fut bâtie sur une qațîa concédée au Préfet Muhammad b. 'Abd Allāh b. Țāhir. La présence traditionnelle du șăhib al-šurța au sommet de la hiérarchie carcérale explique probablement la répartition inégale des prisons dans les quartiers de Bagdad. Sur huit établissements recensés entre $145 / 762$ et le début du IV $/ \mathrm{X}^{\mathrm{e}}$ siècle, six se trouvaient du Côté Ouest - dont trois dans la "ville ronde » ou à proximité immédiate -, et deux semblaient étroitement associées aux sièges de la police et au contrôle des ponts de Bagdad. Cette association n'était pas typiquement bagdadienne : à Sāmarrā' également, la " grande prison » était implantée près du mağlis al-šurat, la Préfecture de police ${ }^{137}$.

Malgré la rareté des informations sur leur architecture, il faut enfin penser que les prisons constituaient un élément marquant du paysage urbain. Elles étaient souvent érigées le long de grands axes, comme à Sāmarrā', où la "grande prison » longeait la rue principale ${ }^{138}$. Seul élément architectural évoqué de manière récurrente, les hautes

\footnotetext{
${ }^{133}$ Ibn Tag̉rī Birdī, al-Nuğūm al-zāhira, Le Caire, al-Mu'assasa l-mișriyya l-āmma, s.d., III, p. 190.

${ }^{134}$ Al-Ya'qūbī, Kitāb al-buldān, p. 260. Voir A. Northedge, The Historical Topography of Samarra, p. 109.

${ }^{135}$ Comme par exemple à al-Mahdiyya sous les Fatimides. N. Hentati, «La prison en Occident musulman médiéval », p. 180. Cf. A. Northedge, The Historical Topography of Samarra, p. 114. Voir al-Munğid, $34^{\mathrm{e}}$ éd., Beyrouth, Dār al-mašriq, 1994, racine ț.b.q.

${ }^{136}$ Al-Balādurīi, Ansāb al-ašrāf, IX, p. 326.

${ }^{137}$ Al-Ya qū $\bar{u} \overline{1}$, Kitāb al-buldān, p. 260. Voir A. Northedge, The Historical Topography of Samarra, p. 109.

${ }^{138}$ O.S.A. Ismail, « The Founding of a New Capital : Sāmarrā’ », BSOAS, 31 (1968), p. 8.
} 
murailles (sūr) qui les entouraient - particulièrement imposantes dans le cas du Mutbaq devaient impressionner les masses. Elles n'étaient pas seulement destinées à empêcher les évasions ; elles marquaient la puissance coercitive de l'État au cœur de la ville - raison pour laquelle elles furent souvent une des premières cibles de la populace lors des émeutes urbaines ${ }^{139}$. Un tel rôle symbolique se manifesta tout particulièrement lors de l'exécution d'al-Hallāğ en 309/922 : tandis que le reste de son corps était incinéré, sa tête, ses mains et ses pieds furent exposés sur les remparts de la Prison nouvelle ${ }^{140}$. En 312/924, certains de ses disciples furent à leur tour arrêtés et Nāzūk, le Préfet de police de Bagdad, leur fit subir un sort comparable : leurs corps furent crucifiés sur la rive orientale et leurs têtes érigées sur les murailles d'une des prisons du Côté Ouest ${ }^{141}$. Comme les palais et les mosquées auxquelles les premières étaient souvent associées -, les hauts murs des prisons rappelaient au quotidien que le salut du peuple dépendait aussi de sa soumission à l'ordre social et politique.

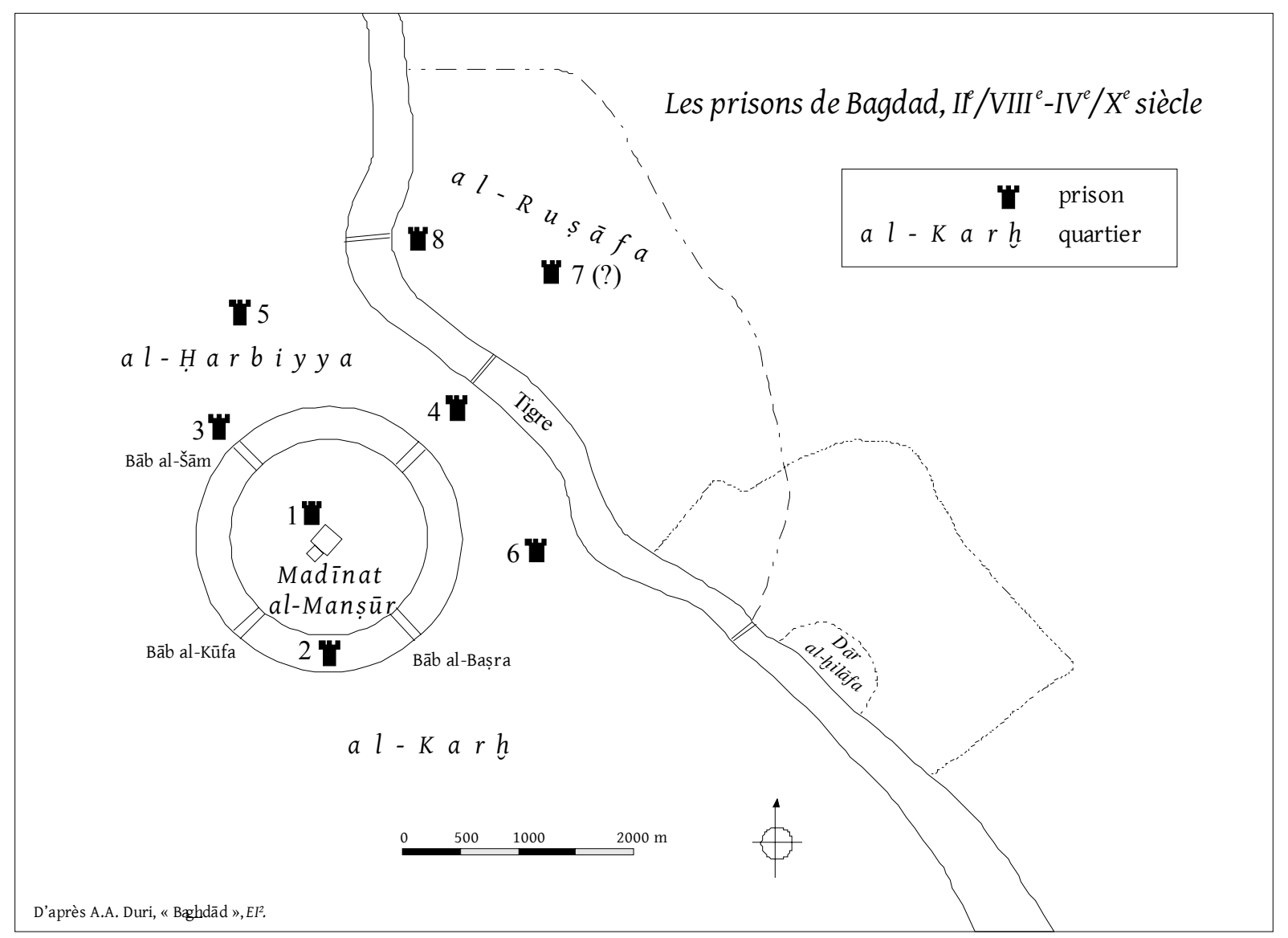

\footnotetext{
${ }^{139}$ Cf. F. Rosenthal, The Muslim Concept of Freedom, p. 65. Voir également Miskawayh, Tağāaib al-umam wa-ta'āqub al-himam, éd. H.F. Amedroz, Oxford, 1920-21, I, p. 74.

${ }^{140}$ Al-Hुatị̂, Ta'rīh Bag̀dād, VIII, p. 127.

${ }^{141} \mathrm{Ibn}$ al-Ğawzī, al-Muntazam, VIII, p. 59.
} 